\title{
Testing Financial Ratios on Business Values of Property and Real Estate Companies Listed in Indonesia Stock Exchange (IDX)
}

\author{
${ }^{1 \times}$ Muhammad Jalari, ${ }^{2}$ Agus Marimin \\ ${ }^{1}$ Sekolah Tinggi IImu Ekonomi Surakarta, Indonesia \\ ${ }^{2}$ Institut Teknologi Bisnis AAS Indonesia \\ Corresponding email: m.jalari64@gmail.com
}

\begin{abstract}
:
This study aims to examine the financial ratios of profitability and solvency to the value of the property and real estate companies in the Indonesia Stock Exchange in the period 2008 - 2018. The data used in this study are secondary data obtained from the IDX. The sample in this study are property and real estate companies listed on the Indonesia Stock Exchange in 2008-2018. Data collection is using documentation techniques, namely by looking at existing documents (financial reports and annual reports). The company's financial statements are obtained from the access website of the Indonesia Stock Exchange (www.idx.co.id) in the period 2008-2018.2018. The results of the study are the company's profitability has a significant effect on the business value of property companies and real estate companies that go public on the Indonesia Stock Exchange (IDX). Company solvency has a negative and significant effect on the Business Value of Property and Real Estate Companies that are Go Public on the Indonesia Stock Exchange (IDX). Simultaneously, the company's profitability and solvency affect the business value of property companies and real estate companies that go public on the Indonesia Stock Exchange (IDX).
\end{abstract}

\section{Keywords:}

financial ratio, company value, property and real estate, IDX

JEL: A10, A19

\section{PRELIMINARY}

According to Harahap (2010: 217) that the value of the company can be measured in several ways, one of which is by analysing financial ratios. The analysis of financial ratios that can be done by investors include liquidity ratios, solvency ratios, profitability ratios, and social activity. These ratios can be used as a tool to measure performance and problems in a company. According to Husnan (2013), the value of a company is the price that prospective buyers are willing to pay if the company is sold. For companies going public, the value of the company can be seen from the value of shares in the capital market, the price of shares traded on the stock exchange is an indicator of company value. With the good value of the company, the company will be considered good by potential investors, and vice versa. According to Arif (2015) that the company's value can reflect the value of assets owned by the company such as securities. There are several factors that affect the value of the company, namely: liquidity, capital structure, dividend policy, company growth, profitability, company size and others. Some of these factors have an inconsistent relationship and influence on company value. Company value can also be influenced by the size of the profitability generated by the company. Profitability is a ratio that is used to assess a company's ability to look for profits or profits in a certain period. This ratio also provides a measure of the level of effectiveness of a company's management which is 
shown from profits generated from sales or from investment income (Kasmir, 2015: 196). The ultimate goal to be achieved by an important company is to obtain maximum profit or profit, in addition to other things. Getting the maximum profit as targeted, the company can increase the value of the company. Profitability ratios can be known how the level of profitability of the company. Every company wants a high level of profitability. To be able to carry on his life, the company must be in a profitable condition (profitable). If the company is in an unfavourable condition, it will be difficult for the company to obtain loans from creditors or investments from outside parties (Van Horne and Wachowicz, 2012: 222).

Financial ratios with two variables namely Solvency and Profitability is a ratio to measure the business value of a company, thus attracting investors to invest their shares in the company. The ratio of solvency is the ratio used to measure the extent of corporate assets financed with debt. This means how much debt burden borne by the company compared to its assets. While the broad meaning is said that the solvency ratio is used to measure the company's ability to pay off all its obligations, both short and long term if the company is dissolved / liquidated (Kasmir, 2008: 151). Another case example quoted from the website www.marketbisnis.com states "Of the 34 property commitments that have released their financial statements for the period 31 December 2017, there were 18 commitments or $53 \%$ that recorded a decline in income with a range of $1 \%$ to $90 \%$. As a whole, the 34 revenue values of these commitments grew by $12.48 \%$, while profits grew by $25.9 \%$. At first glance the value seems high, but the very high performance is only contributed by three commitments, namely BSDE, APLN, and ASRI. The level of income growth of all property commitments if without involving the three companies is only $2.97 \%$, while the profit actually dropped sufficiently to reach $11.2 \%$. The decline in revenue will affect the profitability ratio. According to Van Horne and Wachowicz (2005: 222) profitability ratios consist of two types, namely the ratio that shows profitability in relation to sales and the ratio that shows profitability in relation to investment. Profitability in relation to sales consists of gross profit margin and net profit margin. Profitability in relation to investment consists of the rate of return on total assets and the rate of return on equity.

\section{THEORETICAL REVIEW Company Value}

Company value is the price that prospective buyers are willing to pay if the company is sold. Enterprise value (EV) or firm value (enterprise value) is an important concept for investors, because it is an indicator for the market rate the company as a whole (Nurlela and Islahuddin, (2008). Another opinion by Sudjoko and Soebianto (2007) the value of the company is the perception of investors to the company's level of success related to its share price High stock prices make the value of the company also high, and increase market confidence not only in the company's current performance but also the company's prospects in the future. Company Value is a value that can be used to measure how big the "Level of Interest" of a company is seen from the perspective of several parties such as investors who associate the value of a company from its share price Maximizing the value of a company is the same as maximizing stock prices because high company values identify the prosperity of shareholders. ng high (Gultom et al, 2013: 52). While according to Sundjaja and Berlian (2002: 88) states that valuation is a process that connects risk and taking to determine the value of an asset. Company value can be measured through two approaches, namely the equity approach and the asset approach (Anzlina and Rustam, 2013: 70). Basically the value of the company is an important thing because with high company value will be followed by high share prosperity. The higher the stock price, the higher the value of a 
company. According to Hadianto (2013) high company value is the desire of the owners of the company, because with high value shows the prosperity of shareholders is also high. Wealth of shareholders and companies is represented by market and share prices which are a reflection of investment, funding and asset management decisions. Some of these meanings it can be concluded that what is meant by the value of the company is the price a prospective buyer is willing to pay if the company is sold and reflects the market perspective in assessing the performance and condition of a company.

\section{Profitability}

The definition of profitability according to Brigham (2001: 89) is "a group of ratios that show the combined effect of liquidity, asset management, and debt on operating results". Meanwhile, according to Suad Husnan $(2004 ; 72)$ profitability is a ratio to measure the efficiency of the use of company assets (or maybe a group of company assets). As according to Munawir (2010: 33) profitability is showing the company's ability to generate profits for a certain period. Based on the understanding of profitability according to the experts above, it can be concluded that the profitability ratio is used to measure how much the company's ability to generate net income from activities carried out in an accounting period.

\section{Solvency}

The definition of solvency according to Kasmir (2014: 150) is "solvency or leverage ratio is a ratio used to measure the extent to which a company's activities are financed with debt." Meanwhile, according to Irham Fahmi (2014: 59) solvency is a ratio that shows how a company is able to manage its debt in order to obtain profits and is also able to repay its debt. Another opinion means that solvency shows the company's ability to meet its financial obligations if the company is liquidated, both short-term and long-term financial obligations (Munawir; 2007). Based on the understanding of solvency according to the experts above, it can be concluded that in principle this solvency ratio provides an overview about the level of debt adequacy of the company, in the sense to measure how much the portion of debt in the company when compared with existing capital or assets. Companies that do not have leverage (solvency) means using 100\% capital (Agus Sartono, 2010; 120).

\section{Property and Real Estate Companies}

Today the property and real estate sector is the most important sector in a country, so it is used as an indicator to analyse the economic health of a country, the understanding of the real estate industry according to Indonesian law is listed in PDMN No.5 of 1974 which regulates the real estate industry. Understanding the real estate industry is a property company that is engaged in the supply, procurement, and maturation of land for the needs of industrial businesses, including the tourism industry. While the definition of property according to the Decree of the Minister of Public Housing No.05/KPTS/BKP4N/1995, ps la: 4. Property is land rights or permanent buildings that are the object of the owner and development. Property is the real estate industry coupled with laws such as rent and ownership. According to Santoso (2009) the property and real estate industry is one of the sectors that is giving signals of a country's economic downturn. More and more companies engaged in the property and real estate sector indicate the growing economy in Indonesia. The investment offered in the property and real estate sector is generally long term and will grow in line with economic growth and is believed to be one of the promising investments. From the above understanding it can be concluded that the understanding of 
property and real estate companies is a company that provides various consumer needs in the form of a house or other property. The company functions to help consumers who are in need of a dwelling or anything related to other properties.

\section{METHODOLOGY}

\section{Population, sample and respondent}

The population in this study are property and real estate sector companies listed on the Indonesia Stock Exchange (IDX) for the period 2008-2018.

\section{Table 1}

List of Major Property and Real Estate Company Populations Listed on the Indonesia Stock Exchange in 2008-2018

\begin{tabular}{|c|c|c|c|}
\hline No & Code & Company name & Date of Recording \\
\hline 1 & ACST & Acset Indonusa Tbk. & Jun 242013 \\
\hline 2 & ADHI & Adhi Karya (Persero) Tbk. & Mar 18, 2004 \\
\hline 3 & APLN & Agung Podomoro Land Tbk. & Nov 11,2010 \\
\hline 4 & ASRI & Alam Sutera Realty Tbk. & Dec 18, 2007 \\
\hline 5 & BAPA & Bekasi Asri Pemula Tbk. & Jan 14,2008 \\
\hline 6 & BEST & Bekasi Fajar Industrial Estate & Apr 10, 2012 \\
\hline 7 & BKSL & Sentul City Tbk. & Jul 281997 \\
\hline 8 & BSDE & Bumi Serpong Damai Tbk. & June 6,2008 \\
\hline 9 & CITY & Natura City Developments Tbk. & Sep 28, 2018 \\
\hline 10 & CTRA & Ciputra Development Tbk. & Mar 28, 1994 \\
\hline 11 & DART & Duta Anggada Realty Tbk. & May 8, 1990 \\
\hline 12 & DGIK & Nusa Konstruksi Enjiniring Tbk & Dec 19, 2007 \\
\hline 13 & DILD & Intiland Development Tbk. & Sep 41991 \\
\hline 14 & DMAS & Puradelta Lestari Tbk. & May 29,2015 \\
\hline 15 & FORZ & Forza Land Indonesia Tbk. & Apr 28, 2017 \\
\hline 16 & GAMA & Gading Development Tbk. & Jul 112012 \\
\hline 17 & GPRA & Perdana Gapuraprima Tbk. & October 10,2007 \\
\hline 18 & GWSA & Greenwood Sejahtera Tbk. & Dec 23, 2011 \\
\hline 19 & IDPR & Indonesia Pondasi Raya Tbk. & Dec 102015 \\
\hline 20 & JKON & Jaya Konstruksi Manggala Prata & Dec 42007 \\
\hline 21 & JRPT & Jaya Real Property Tbk. & June 29, 1994 \\
\hline 22 & KIJA & Kawasan Industri Jababeka Tbk. & January 10, 1995 \\
\hline 23 & KOTA & DMS Propertindo Tbk. & Jul 092019 \\
\hline 24 & LPCK & Lippo Cikarang Tbk & Jul 24, 1997 \\
\hline 25 & LPKR & Lippo Karawaci Tbk. & June 28,1996 \\
\hline 26 & MDLN & Modernland Realty Tbk. & Jan 18, 1993 \\
\hline 27 & MTLA & Metropolitan Land Tbk. & June 20, 2011 \\
\hline 28 & NRCA & Nusa Raya Cipta Tbk. & Jun 272013 \\
\hline 29 & NZIA & Nusantara Almazia Tbk. & 25 September 2019 \\
\hline 30 & PAMG & Bima Sakti Pertiwi Tbk. & 05 Jul 2019 \\
\hline 31 & PBSA & Paramita Bangun Sarana Tbk. & Sep 28, 2016 \\
\hline 32 & PLIN & Plaza Indonesia Realty Tbk. & June 15,1992 \\
\hline 33 & POLL & Pollux Properti Indonesia Tbk. & Jul 112018 \\
\hline 34 & PPRO & PP Properti Tbk. & May 19,2015 \\
\hline 35 & PTPP & PP (Persero) Tbk. & Feb. 9, 2010 \\
\hline 36 & PWON & Pakuwon Jati Tbk. & October 9, 1989 \\
\hline 37 & RBMS & Ristia Bintang Mahkotasejati T & Dec. 19,1997 \\
\hline 38 & RDTX & Roda Vivatex Tbk & May 14,1990 \\
\hline 39 & RISE & Jaya Sukses Makmur Sentosa Tbk & Jul 092018 \\
\hline
\end{tabular}




\begin{tabular}{|c|c|l|l|}
\hline No & Code & \multicolumn{1}{|c|}{ Company name } & \multicolumn{1}{|c|}{ Date of Recording } \\
\hline 40 & SMRA & Summarecon Agung Tbk. & May 7, 1990 \\
\hline 41 & SSIA & Surya Semesta Internusa Tbk. & Mar 27, 1997 \\
\hline 42 & TARA & Sitara Propertindo Tbk. & Jul 11 2014 \\
\hline 43 & TOPS & Totalindo Eka Persada Tbk. & Jun 162017 \\
\hline 44 & TOTL & Total Bangun Persada Tbk. & July 25, 2006 \\
\hline 45 & WEGE & Wijaya Karya Bangunan Gedung & Nov 30, 2017 \\
\hline 46 & WIKA & Wijaya Karya (Persero) Tbk. & 29 Oct 2007 \\
\hline 47 & WSKT & Waskita Karya (Persero) Tbk. & Dec 19, 2012 \\
\hline
\end{tabular}

Source: $h t t p: / / w w w . i d x . c o . i d$.

Table 2

List of Population Property and Real Estate Development Companies Listed on the Indonesia Stock Exchange in 2008-2018

\begin{tabular}{|c|c|c|c|}
\hline No & Code & Company name & Date of Recording \\
\hline 1 & ARMY & Armidian Karyatama Tbk. & Jun 212017 \\
\hline 2 & BAPI & Bhakti Agung Propertindo Tbk. & Sep 162019 \\
\hline 3 & $\mathrm{BCIP}$ & Bumi Citra Permai Tbk. & Dec 11, 2009 \\
\hline 4 & BIKA & Binakarya Jaya Abadi Tbk. & Jul 142015 \\
\hline 5 & BIPP & Bhuwanatala Indah Permai Tbk. & October 23, 1995 \\
\hline 6 & BKDP & Bukit Darmo Property Tbk & 15 June 2007 \\
\hline 7 & COWL & Cowell Development Tbk. & Dec 19, 2007 \\
\hline 8 & CPRI & Capri Nusa Satu Properti Tbk. & Apr 112019 \\
\hline 9 & CSIS & Cahayasakti Investindo Sukses & May 10,2017 \\
\hline 10 & DUTI & Duta Pertiwi Tbk & November 2, 1994 \\
\hline 11 & ELTY & Bakrieland Development Tbk. & October 30, 1995 \\
\hline 12 & EMDE & Megapolitan Developments Tbk. & Jan 12, 2011 \\
\hline 13 & FMII & Fortune Mate Indonesia Tbk & 30 June 2000 \\
\hline 14 & GMTD & Gowa Makassar Tourism Developm & Dec 11, 2000 \\
\hline 15 & LAND & Trimitra Propertindo Tbk. & 23 Aug 2018 \\
\hline 16 & LCGP & Eureka Prima Jakarta Tbk. & Jul 132007 \\
\hline 17 & MABA & Marga Abhinaya Abadi Tbk. & Jun 222017 \\
\hline 18 & $\mathrm{MKPI}$ & Metropolitan Kentjana Tbk. & Jul 102009 \\
\hline 19 & MMLP & Mega Manunggal Property Tbk. & June 12,2015 \\
\hline 20 & MPRO & Maha Properti Indonesia Tbk. & Oct 92018 \\
\hline 21 & MTRA & Mitra Pemuda Tbk. & Feb 10, 2016 \\
\hline 22 & MTSM & Metro Realty Tbk. & January 8, 1992 \\
\hline 23 & MYRX & Hanson International Tbk. & 31 October 1990 \\
\hline 24 & NIRO & City Retail Developments Tbk. & Sep 13, 2012 \\
\hline 25 & OMRE & Indonesia Prima Property Tbk & Aug 22, 1994 \\
\hline 26 & POLI & Pollux Investasi Internasional & Jan 102019 \\
\hline 27 & POSA & Bliss Properti Indonesia Tbk. & May 10, 2019 \\
\hline 28 & RIMO & Rimo International Lestari Tbk & Nov 10,2000 \\
\hline 29 & RODA & Pikko Land Development Tbk. & Oct 222001 \\
\hline 30 & SATU & Kota Satu Properti Tbk. & 05 November 2018 \\
\hline 31 & SCBD & Danayasa Arthatama Tbk. & Dec 312019 \\
\hline 32 & SKRN & Superkrane Mitra Utama Tbk. & Oct 112018 \\
\hline 33 & SMDM & Suryamas Dutamakmur Tbk. & 12 October 1995 \\
\hline 34 & URBN & Urban Jakarta Propertindo Tbk. & Dec 102018 \\
\hline
\end{tabular}

Source: $h t t p: / / w w w . i d x . c o . i d$. 
The sample is part of the number of characteristics that have a population (Sugiyono, 2014: 62). Samples taken from the population must be truly representative (represent) because what is learned from the sample conclusions will represent the population. The selection of research samples is based on the nonprobability sampling method precisely the purposive sampling method. The sample of this research is companies that belong to the property and real estate sector which were listed on the Indonesia Stock Exchange (IDX) in the period 2008-2018. The characteristics used to select the sample in this study are Registered on the Indonesia Stock Exchange (IDX) in 2008-2018 in the property and real estate industry group which publishes annual reports in a row in 2008-2018. financial statements ending December 31, complete with notes to the financial statements (CALK). Property and real estate companies that use Rupiah as their financial reporting currency. Property and real estate companies that have submitted data in the form of consecutive financial statements in 2008-2018 containing data and information that can be used in this study, as well as audited financial statements and accompanied by an independent auditor's report.

The following is a sample of research on property and real estate companies listed on the Indonesia Stock Exchange (BEI) for the period 2008-2018, which can be seen in Table 3.

Table 3

Research Samples

\begin{tabular}{|c|c|c|c|}
\hline No & Code & Company name & Date of Recording \\
\hline 1 & $\mathrm{ADHI}$ & Adhi Karya (Persero) Tbk. & Mar 18, 2004 \\
\hline 2 & ASRI & Alam Sutera Realty Tbk. & Dec 18, 2007 \\
\hline 3 & BAPA & Bekasi Asri Pemula Tbk. & Jan 14,2008 \\
\hline 4 & BKSL & Sentul City Tbk. & Jul 281997 \\
\hline 5 & CTRA & Ciputra Development Tbk. & Mar 28, 1994 \\
\hline 6 & DART & Duta Anggada Realty Tbk. & May 8, 1990 \\
\hline 7 & DGIK & Nusa Konstruksi Enjiniring Tbk & Dec 19, 2007 \\
\hline 8 & DILD & Intiland Development Tbk. & Sep 41991 \\
\hline 9 & GPRA & Perdana Gapuraprima Tbk. & October 10, 2007 \\
\hline 10 & JKON & Jaya Konstruksi Manggala Prata & Dec 42007 \\
\hline 11 & JRPT & Jaya Real Property Tbk. & June 29, 1994 \\
\hline 12 & $\mathrm{KIJA}$ & Kawasan Industri Jababeka Tbk. & January 10,1995 \\
\hline 13 & LPCK & Lippo Cikarang Tbk & Jul 24, 1997 \\
\hline 14 & LPKR & Lippo Karawaci Tbk. & June 28,1996 \\
\hline 15 & MDLN & Modernland Realty Tbk. & Jan 18, 1993 \\
\hline 16 & PLIN & Plaza Indonesia Realty Tbk. & June 15,1992 \\
\hline 17 & PWON & Pakuwon Jati Tbk. & October 9,1989 \\
\hline 18 & RBMS & Ristia Bintang Mahkotasejati T & Dec. 19,1997 \\
\hline 19 & RDTX & Roda Vivatex Tbk & May 14,1990 \\
\hline 20 & SMRA & Summarecon Agung Tbk. & May 7, 1990 \\
\hline 21 & SSIA & Surya Semesta Internusa Tbk. & Mar 27, 1997 \\
\hline 22 & TOTL & Total Bangun Persada Tbk. & July 25,2006 \\
\hline 23 & WIKA & Wijaya Karya (Persero) Tbk. & 29 Oct 2007 \\
\hline 24 & BIPP & Bhuwanatala Indah Permai Tbk. & October 23, 1995 \\
\hline 25 & BKDP & Bukit Darmo Property Tbk & 15 June 2007 \\
\hline 26 & COWL & Cowell Development Tbk. & Dec 19, 2007 \\
\hline 27 & DUTI & Duta Pertiwi Tbk & November 2, 1994 \\
\hline 28 & ELTY & Bakrieland Development Tbk. & October 30, 1995 \\
\hline 29 & FMII & Fortune Mate Indonesia Tbk & 30 June 2000 \\
\hline 30 & GMTD & Gowa Makassar Tourism Developm & Dec 11, 2000 \\
\hline
\end{tabular}




\begin{tabular}{|l|l|l|l|}
\hline No & Code & \multicolumn{1}{|c|}{ Company name } & \multicolumn{1}{|c|}{ Date of Recording } \\
\hline 31 & LCGP & Eureka Prima Jakarta Tbk. & Jul 13 2007 \\
\hline 32 & MTSM & Metro Realty Tbk. & January 8, 1992 \\
\hline 33 & MYRX & Hanson International Tbk. & 31 October 1990 \\
\hline 34 & OMRE & Indonesia Prima Property Tbk & Aug 22, 1994 \\
\hline 35 & RIMO & Rimo International Lestari Tbk & Nov 10, 2000 \\
\hline 36 & RODA & Pikko Land Development Tbk. & Oct 22 2001 \\
\hline 37 & SMDM & Suryamas Dutamakmur Tbk. & 12 October 1995 \\
\hline
\end{tabular}

The sampling technique used in this study is nonprobability sampling with a purposive sampling approach . Arikunto (2010: 183) explains that positive sampling is done by taking subjects not based on strata, random, or region but based on the existence of certain objectives. Purposive sampling is a sampling technique with certain considerations (Sugiyono, 2014: 85). That is, each subject drawn from the population is chosen intentionally based on certain objectives and considerations, or it can also be said that the selection of samples is in accordance with the characteristics that have been determined.

\section{Method of Collecting Data}

The data collection method in this study uses the direct observation method (conducted by the researchers themselves). Data collection techniques in a direct observation method, namely: Research Field (Field Research) This research was conducted to obtain data about the secondary in this case the property sector companies that go public which has been listed on the Indonesia Stock Exchange (IDX) Research Library (Library Research) Studying the theory and references related to the topic of language to compile this thesis, as well as data collection is done by studying all related material.

\section{Data Analysis Method}

The research method used in this study is a comparative causal research method. According to Indrianto and Supomo (2002: 27) "Comparative causal research is a type of research with the characteristics of problems in the form of a causal relationship between two or more variables. Comparative causal research is a type of ex post facto research, namely the type of research on data collected after the occurrence of a fact or event. Researchers can identify facts or events as variables that are affected (dependent variables) and conduct an investigation of the variables that influence (independent variables)".

\section{RESULTS AND DISCUSSION}

The description of research data based on financial statements in the form of financial ratios from publication reports as published and tabulated as shown in the following table.

\section{Table 4}

Description of Financial Data on Property Companies and Real Estate 2008 - 2018 \begin{tabular}{l|l|l|l|l}
$\mathrm{N}$ & Minimum & Maximum & The mean & Std. Deviation \\
\hline
\end{tabular}

\begin{tabular}{|c|c|c|c|c|c|}
\hline Company Value (PBV) & 407 & 0.25 & 4.26 & 2,2136 & 1.15443 \\
\hline Profitability (NPM) & 407 & 3.24 & 18.17 & 10,9660 & 4.25906 \\
\hline Solvency (DER) & 407 & .15 & 2.58 & 1.3809 & 0.69545 \\
\hline Valid N (listwise) & 407 & & & & \\
\hline
\end{tabular}


Based on the results of the processing of descriptive statistical data it can be seen as shown in table 4 above, that the value of the company measured by book value (price book value) has a range between 0.25 to a maximum of 4.26 with an average of 2.2136 and deviations standard of 1.1544 . The value of a company's profitability measured or proxied by the value of a profit margin (net profit margin) has a range of values between 3.24 to a maximum of 18.17 with an average of 10.966 and a standard deviation of 4.259 . The company's solvency value which is proxied by its leverage or Debt to Equity Ratio (DER) obtained a range between 0.15 to a maximum of 2.58 with an average of 1.3809 and a standard deviation of 0.69545 .

Based on normality test with the results of data processing using the KolmogorovSmirnov model, the results are as shown in table 4.

Table 5

Residual Regression Normality Test

One-Sample Kolmogorov-Smirnov Test

\begin{tabular}{|c|c|c|}
\hline & & $\begin{array}{c}\text { Unstandardized } \\
\text { Residual } \\
\end{array}$ \\
\hline \multicolumn{2}{|l|}{$\mathrm{N}$} & 407 \\
\hline \multirow{2}{*}{ Normal Parameters ${ }^{\mathrm{a}, \mathrm{b}}$} & The mean & 0.00 million \\
\hline & Std. Deviation & 0.90633499 \\
\hline \multirow[t]{3}{*}{ Most Extreme Differences } & Absolute & 0.080 \\
\hline & Positive & 0.067 \\
\hline & Negative & $-0,080$ \\
\hline Statistical Test & & .621 \\
\hline Asymp. Sig. (2-tailed) & & .190 \\
\hline
\end{tabular}

Based on the test results it appears that the data used for the regression test for the residuals are normally distributed. This can be seen from the value $\rho$ value $(0,151)>0,05$.

Table 6

Multicollinearity Data Regression Test

\begin{tabular}{|l|r|r|}
\hline \multicolumn{1}{|c|}{ Variable } & Tolerance & VIF \\
\hline Profitability (NPM) & 0,981 & 1,019 \\
\hline Solvency (DER) & 0,981 & 1,019 \\
\hline
\end{tabular}

Based on the test results it appears that the data used for the regression test there are no variables that have the effect of serial correlation (multicollinearity) because the results of the VIF value is less than 10 or a tolerance value of more than 0.1 .

The results of heteroscedasticity testing with the Glejser test are shown as in the following table :

Table 7

Heteroscedasticity Test Data Regression Glejser Test

Coefficients $^{\text {a }}$

Unstandardized Standardized

Coefficients Coefficients

\begin{tabular}{|c|c|c|c|c|c|c|}
\hline \multicolumn{2}{|c|}{ Model } & B & Std. Error & Beta & $\mathrm{t}$ & Sig. \\
\hline 1 & (Constant) & 1,070 & 0.088 & & 12,207 & 0,000 \\
\hline & Interest rate & -0.008 & 0.006 & $-0,061$ & $-1,288$ & .198 \\
\hline & Capital Structure & 0.004 & 0.040 & 0.005 & .109 & 0.914 \\
\hline
\end{tabular}


Seemed that in the table above, none of the independent variable (either the interest rate, capital structure, as well as the size of the company) yes $n g$ a significant $(p<0.05)$ in the positive residual value. So it can be concluded that in the regression model of this study there is no influence (symptoms) of heteroscedasticity. The results of testing for heteroscedasticity with Plots test between the predicted value of the dependent variable (ZPRED) and the residual (SRESID). So that it can be stated that the residuals in the study have no symptoms because the data distribution is still in the range of -2 to +2 , as shown in the following graph.

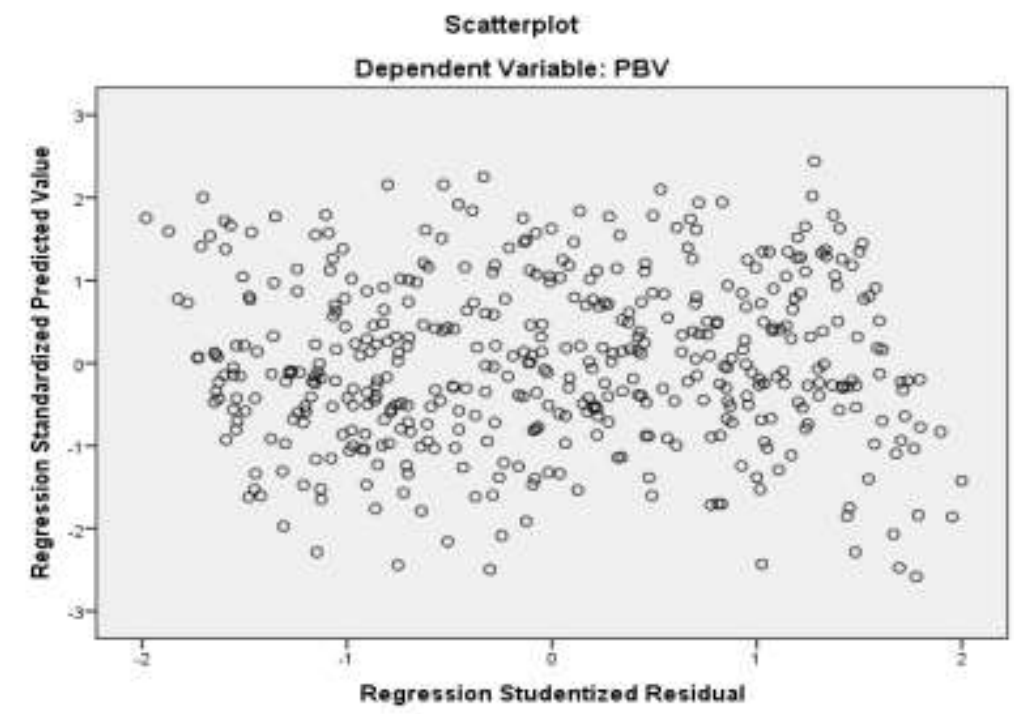

Picture 1.

Graph of Heteroscedasticity Test

Based on the results of heteroscedasticity testing with the scatter plot test method, it can be seen that the points that represent the variants of the research data are spread evenly and do not form a specific pattern, so that it can be known in the regression test that there are no symptoms of heteroscedasticity.

Testing the hypothesis of this study tested the effect of independent variables on the dependent variable. Hypothesis testing is based on the effects of the variables studied by the method of multiple linear regression, $t$ test, and $F$ test, each of which is explained as follows.

1. Linear Regression Test

Based on the results of data processing regression models for: PBV $=\beta_{0}+\beta_{1}$ NPM + $\beta_{2} \mathrm{DER}+\mathrm{e}$ Can be explained in the results of data processing as shown in the following table:

Table 8 .

Summary of Multiple Linear Regression Analysis Results

\begin{tabular}{|l|c|c|c|}
\hline \multicolumn{1}{|c|}{ Variable } & Coefficient & t count & Sig (prob = 0.05) \\
\hline Profitability (NPM) & 0.032 & 2,484 & 0,013 \\
\hline Solvency (DER) & $-0,170$ & $-2,168$ & 0.031 \\
\hline Constants $: 2,100$ & & \\
F-count $: 4,784$ Sig. 0, 009 & \\
$\mathrm{R}^{2}: 0,203$ \\
Adj. $\mathrm{R}^{2}: 0,190$
\end{tabular}

Source: Secondary data processed

Estimated regression: $\mathrm{PBV}=2,100+0,032 \mathrm{NPM}-0,170 \mathrm{DER}+\mathrm{e}$ 
The estimation regression model can be used to predict or predict the value of a company based on the following estimates: A constant value of 2.100 indicates a fixed value of the company based on the PBV size if it is considered that there is no influence from the studied variables ie Profitability and Solvability are considered zero (none). Profitability Regression Coefficient of 0.032 is a positive value indicating that if there is an effect of the profitability variable with changes increasing by one unit, it will increase the value of the company by 0.032 units. Solvency Regression Coefficient of 0.170 is a negative value indicating that if there is an influence of the Solvency variable with changes increasing by one unit, it will reduce the value of the company by 0.170 units. The $t$ test for NPM (Net Profit Margin) is a proxy of the Profitability Ratio The t test was conducted to test the significance or significance of the level of influence of the independent profitability variable (NPM) on the firm value dependent variable (PBV). Based on the test results obtained $t$-count value for UP of 2.484. Hypothesis: Ho $\beta_{3}=0$ There is no influence between NPM (Profitability) and firm value (PBV). $\mathrm{Ha} \beta_{3} \neq 0$ There is an influence between NPM (profitability) with the value of the company (PBV). Level of significant $(\alpha)=0.05$, then $t$ table $=1.980$ Based on the test results obtained $t_{\text {count }}=2.484$. Test criteria: $t_{\text {count }}>t_{\text {table }}$ or $t_{\text {count }}<-t_{\text {table }}$, then reject Ho- $t_{\text {table }}<$ $t_{\text {count }}<t_{\text {table }}$, then accept Ho.

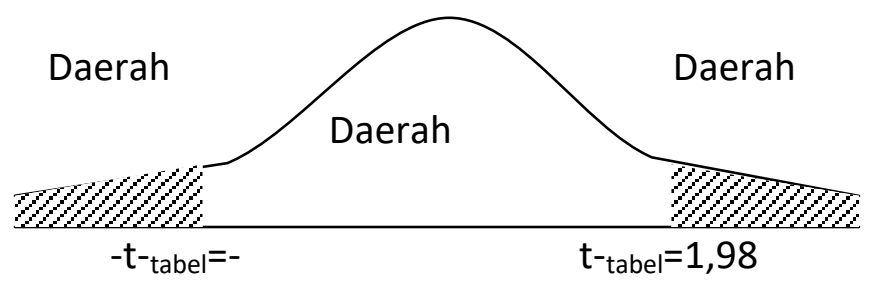

Figure 2

Test Chart t NPM ( Profitability )

Based on the test results obtained $t$-count $=2.484>\mathrm{t}$-table $=1.98$, then $\mathrm{Ho}$ is rejected. So it can be seen that profitability (NPM) significantly influences the value of the company (PBV) for 10 years, from 2008-2018. This shows that if the profitability of a company increases, it also affects the value of the company based on (PBV) positively. This means that increasing profitability will increase company value. The t test for DER (Debt to Equity Ratio) which is a proxy of the Solvency Ratio Test was conducted to test the significance or significance of the influence of the independent variable Debt to Equity Ratio (DER) on the dependent variable Company Value (PBV). Based on the test results obtained $t$ value calculate for DER of $-2,168$. Hypothesis: Ho $\beta_{2}=0$ There is no influence between DER (Debt to Equity Ratio) with firm value (PBV). Ha $\beta_{2} \neq 0$ There is an influence between DER (Debt to Equity Ratio) with the value company (PBV). Level of significance $(\alpha)=0.05$, then $t_{\text {table }}=$ 1.980 Based on the test results obtained $t-$ count $=-2.168$. Test criteria: $t_{\text {count }}>t_{\text {table }}$ or $t_{\text {test }}<-t_{\text {table }}$, then reject $\mathrm{Ho}-\mathrm{t}_{\text {table }}<\mathrm{t}_{\text {count }}<\mathrm{t}_{\text {table }}$, then accept $\mathrm{Ho}$

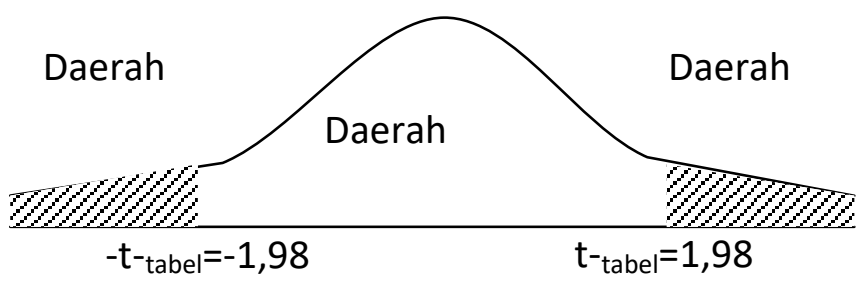

Figure 3

Test Chart of Capital Structure (DER) 
Based on the test results obtained $t$ count $=-2,168>t-t_{\text {table }}=-1.98$, then $\mathrm{Ho}$ is rejected. So it can be seen that Debt to Equity Ratio (DER) has a significant effect on the value of the company (PBV) for 10 years from 08-08-2018. This shows that if the solvability ratio of a company increases, it also negatively affects the value of the company based (PBV). This means that increasing the ratio of solvability will reduce the value of the company.

The $\mathrm{F}$ test is used to test the significance of whether simultaneously the variables in the model (independent variables) can explain the dependent variable namely the company

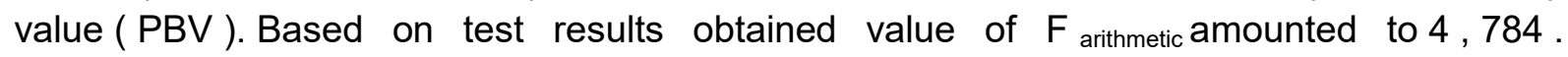
Hypostasis: Ho : $\beta_{1}=\beta_{2}=0$ there is no influence between (NPM, and DER) variables to the value of the company (PBV) .h $A: \beta \square_{1} \neq \beta \square_{2} \neq 0$ There is no influence between variance 1 (NPM, and DER) on firm value (PBV). Level of significant $(\alpha)=0,05$, $F_{\text {table }}=3,01$ Based on test results obtained $F_{\text {count }}=4,784$. Testing criteria : $F_{\text {count }}>F_{\text {table }}$, rejecting $\mathrm{Ho}_{\text {count }}<\mathrm{F}$ table , then accept Ho

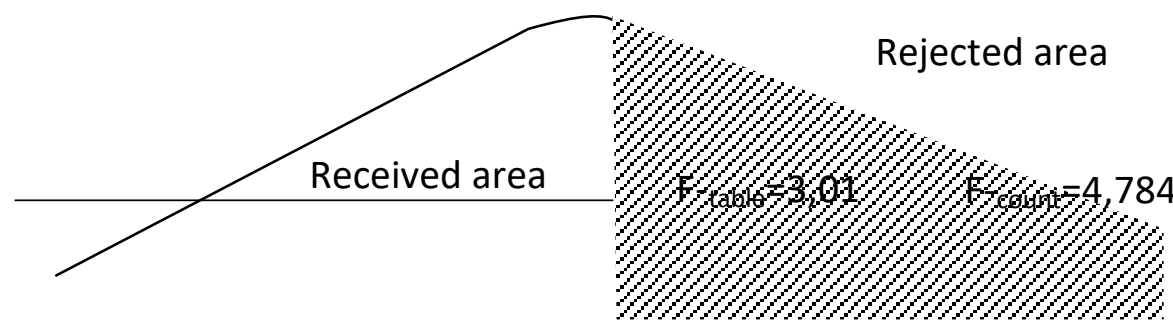

Figure 4

Test Chart F Company Value ( PBV )

Based on the test results obtained $F$ - $_{\text {count }}=4,784>F_{- \text {table }}=3,01$, then Ho is rejected. So it can be concluded that simultaneously there is the effect of profitability, and solvency on firm value.

\section{Discussion}

1. Effect of Profitability on the Business Value of Property Companies and Real Estate Companies that Go Public on the Indonesia Stock Exchange (IDX)

Profitability is a picture of management's performance in managing a company and is one of the factors that investors refer to in buying shares. For companies, increasing profitability is a must so that company shares remain attractive to investors. Investors do an overview of a company by looking at financial ratios as an investment evaluation tool, because financial ratios reflect the high and low values of the company. If investors want to see how much the company generates the return on investment that they invest, what will be seen is the profitability ratio, especially the net profit margin (NPM), because this ratio measures how effectively the company generates profits for investors. The results of a partial test of the effect of profitability by measuring net profit margin (NPM) can be seen in table 5 that the $t_{\text {count }}$ is 2.484 with a significance of $0.013(p<0.05)$ which gives the conclusion that profitability (NPM) has a significant effect on the value of the company (PBV) for 10 years ie from 2008-2018 This shows that if the profitability of a company increases, it also affects the value of the company based on (PBV) positively. This means that increasing profitability will increase company value. In accordance with research that was conducted by Alfredo Mahendra DJ in 2011 which gave the results that Liquidity had a significant positive effect on firm value and Profitability had a significant positive effect on firm value. 
2. Effect of Solvency on the Business Value of Going Property and Real Estate Companies on the Indonesia Stock Exchange (IDX)

Solvency Ratio is a ratio used to measure the extent to which a company's assets are financed with debt. This means how much debt burden borne by the company compared to its assets. While the broad meaning is said that the Solvency ratio is used to measure the company's ability to pay off all its obligations, both short and long term if the company is dissolved / liquidated (Kasmir, 2008). Solvency shows the proportion of the use of debt to finance its investment Sartono (2010: 120). The higher the leverage, the value of the company will decrease too, meaning that leverage negatively affects the value of the company. The results of the study show that the t-test is $-2,168$ with a significance value of 0.031 , thus $p<0.05$. This shows that Debt to Equity Ratio (DER) as a measure of the value of leverage (Solvency) has a negative and significant effect on the value of the company (PBV) for 10 years from 2008-2018. This means that increasing the Solvency ratio will reduce the value of the company.

In line with the results of Wina's study (2016), which shows that Solvency and Profitability affect the value of the company in property and Real Estate companies listed on the Indonesia Stock Exchange, where each increase in the value of Solvency and Profitability will increase the value of the company.

3. Effect of Profitability and Solvency on the Business Value of Property Companies and Real Estate Companies that Go Public on the Indonesia Stock Exchange (IDX)

There are several factors that affect the value of the company, namely: liquidity, capital structure, dividend policy, company growth, profitability, company size and others (Arif, 2015). This study takes several factors that are considered to have the most close relationship with company value, namely profitability and solvency factors. The results of this study indicate that the profitability and solvency factors are both able to influence simultaneously on the company value of Property and Real Estate that go public on the Indonesia Stock Exchange. Evidenced by the $F$ test results of 4.784 significant $(0.009)$ $<0.05$. So that it can be seen that there is a simultaneous influence of profitability, and solvency on company value. In general, many methods and techniques have been developed in the valuation of the company, including; 1) approach to profit, the method of the ratio of the rate of profit or price earnings ratio and the method of capitalization of protection of profit, 2) cash flow approach, the discounted cash flow method, 3) divident approach, the method of growth d i VIDEN, 4) approach to asset, the method of valuation of assets, 5) share price approach, 6) approach to economic value added (Michell Suharli 2006; 3).Weston and Copeland (1995) explain

\section{CONCLUSIONS AND IMPLICATIONS}

Based on the results of research and discussion, it can be concluded that: Company profitability has a significant effect on the Business Value of Property Companies and Real Estate Companies that Go Public on the Indonesia Stock Exchange (IDX). Company solvency has a negative and significant effect on the Business Value of Property Companies and Real Estate Companies that Go Public on the Indonesia Stick Exchange (IDX). Simultaneously, the company's profitability and solvency affect the business value of property companies and real estate companies that go public on the Indonesia Stock Exchange (IDX). 


\section{LIMITATIONS AND FUTURE RESEARCH}

Company profitability affects the Business Value of Property Companies and Real Estate Companies that go public on the Indonesia Stock Exchange (IDX), therefore it is very necessary for companies to pay attention to their financial performance, especially the profit factor that is measured on profits and stock returns. Solvency companies a significant negative effect on the Business Value of Corporate Property and Real Estate that go public in Indonesia Stock Exchange (IDX), therefore it is very necessary for the company so that the company is able to maintain capital that is used to reduce the level of debt, so that the existing capital will be effectively used, because with increasing the value of leverage it is possible to reduce the value of the company, where the results of research on this factor show a negative effect. This means that an increase in debt means a decrease in company value. Profitability and solvency were able to significantly affect the Company's Business Value. This means that the company should also need to improve its overall financial performance, because in addition to these two factors the company's value is also influenced by other factors such as the value of stock returns.

For investors who want to invest in the company and the property sector Real Estate, should pay attention to the profitability variables because these variables are factors that can affect the value of the company. Based on the debt ratio, which is measured by the solvability value, the company should be able to balance between the use of debt with operational costs that can be possible to have a negative impact on the company's value. So that the use of long-term loans will be taxable. That tax utilization should be used wisely. Then the increasing value of the company will prosper the company and its shareholders.

For property and real estate companies, you should pay attention to the debt factor variable. Because the value of the company is influenced by the debt factor which is proxied by the value of its leverage, the company should be more precise in the use of assets owned by the company to get loans from outside (debt) and the company's assets should be used for company operations in order to obtain high profits.

For research similar to current research, henceforth in order to be able to dig up more information related to relevant variables to be tested related to its influence on company value both expanding research variables or using research objects of all companies listed on the Indonesia Stock Exchange with the industrial sector from every company.

\section{BIBLIOGRAPHY}

Agus Sartono. (1997). Financial management. Yogyakarta: BPFE.

Agus Sartono. (2010). Financial Management Theory and Applications (4th ed.). Yogyakarta: BPFE.

Arikunto, S, (2010), Qualitative and Quantitative Research Procedures. Jakarta: Rineka Cipta.

Arif, (2015), The Effect of Capital Structure, Return on Equity, Liquidity, and Growth Opportunity on Company Value in Service Companies Listed on the Indonesia Stock Exchange. Thesis, Faculty of Economics. Yogyakarta State University.

Brealey, Myers, Marcus. (2007). Fundamentals of Corporate Financial Management. Volume 2. Fifth Edition. Jakarta: Erlangga.

Brigham, EF and JF Houston. (2001). Fundamentals of Financial Management . Jakarta: Selemba Empat.

Brigham, EF and JF Houston. (2006). Fundamentals of Financial Management. 10th edition. Jakarta: Selemba Empat.

Cashmere. (2014). Financial Statement Analysis. Issue One. Seventh Printing. Jakarta: PT Raja Grafindo Persada. 
Cashmere. (2008). Financial Statement Analysis. Issue One. First printing. Jakarta: PT Raja Grafindo Persada.

Cashmere. (2015). Analysis of financial statements. Jakarta: Rajawali Press.

Gultom Robinhot DKK, (2013), Analysis of Factors Affecting Company Value in Pharmaceutical Companies on the Indonesia Stock Exchange. Journal of Microeconomic Entrepreneurs, Vol.3. No. 01, April 2013.

Hadianto (2013). Analysis of the Effect of Financial Performance on Firm Value with CSR and GCG Disclosures as Variable Modifiers. Thesis. Diponegoro University. Semarang. Husnan, S. (2013). Financial Management Theory and Application. Jakarta: Selemba Empat.

Horne, James C. Van and John M. Wachowicz, Jr. (2012). Principles of Financial Management. 13th Edition. Book 1. Jakarta: Selemba Empat.

Horne, James C. Van and Sinaga, Marianus. 1994. Fundamentals of Financial Management. Jakarta: Erlangga.

Harahap, Sofyan Syafri. (2002). Accounting Theory. Jakarta: PT. Raja Grafindo Persada.

Harahap, Sofyan Syafri. (2008). Critical analysis of financial statements. Jakarta: PT. Raja Grafindo Persada.

https://gopublic.idx.co.id. Accessed November 20, 2019.

https://properti.kompas.com. Accessed December 15, 2019.

https: //www.idx.co.id. Accessed November 20, 2019.

https://tirtasinangka.wordpress.com . Accessed December 15, 2019.

http://repository.usu.ac.id//Chapter\%2. Accessed January 5, 2020.

Indriantoro, N \& Supomo, B (2002). Business Research Methodology for Accounting and Management, first edition, Yogyakarta: BPFE

Irham Fahmi. (2012). Financial Performance Analysis. Bandung: Alfabeta.

Munawir. (2002). Analysis of financial statements. Fourth edition. Yogyakarta: Liberty.

Munawir. (2007). Analysis of financial statements. Fourth edition. Yogyakarta: Liberty.

Munawir. (2010). Analysis of financial statements. Yogyakarta: Liberty.

Santoso, Singgih. (2009). Using SPSS for Non-Parametric Statistics. Jakarta: PT. Elex Media Komputindo.

Suad Husnan and Enny Pudjiastuti. (2004). Fundamentals of Financial Management. Yogyakarta: UPP AMP YKPN.

Sundjaja, Ridwan and Berlian, Inge. (2002). Financial management. Jakarta: Prenhallindo.

Sugiyono (2012). Statistics for Research. 21st printing. Bandung: Alfabeta.

Sugiyono (2014). Qualitative Quantitative Research Methods and R\&D. Bandung: Alfabeta. 